\title{
Front Matter: Volume 10261
}

, "Front Matter: Volume 10261," Proc. SPIE 10261, Infrared Thin Films: A Critical Review, 1026101 (1 January 1992); doi: 10.1117/12.2284582

SPIE. Event: Critical Reviews, 1991, San Jose, CA, United States 


\section{Contents}

\section{DESIGN AND MANUFACTURE OF IR THIN FILMS}

3 Design of transparent conductive coatings and filters M. Kohin, S. J. Wein, J. D. Traylor, R. C. Chase, J. E. Chapman, Litton Itek Optical Systems.

35 All-polymeric infrared reflecting films

W. J. Schrenk, R. A. Lewis, J. A. Wheatley, C. B. Arends, Dow Chemical Co.

50 Infrared thin film polarization preserving reflectors

B. E. Perilloux, Coherent, Inc.

71 Far-IR multilayer filter design: manufacture and application in remote sensing

J. S. Seeley, Univ. of Reading (UK).

\section{MATERIALS AND PROCESSES}

91 Boron phosphide IR coatings

B. C. Monachan, D. Morrison, E. M. Waddell, D. R. Gibson, A. D. Wilson, Pilkington Optronics (UK); K. L. Lewis, Defence Research Agency (UK).

124 Ion-beam deposition of fluoride thin films G. A. Al-Jumaily, Jet Propulsion Lab.

\section{APPLICATIONS}

141 Thin film coatings for improved IR detector performance

J. E. Rudisill, H. T. Nguyen, Laser Power Optics.

156 Electrochromic IR coatings: properties, prospects, and problems C. G. Granqvist, Chalmers Univ. of Technology and Univ. of Gothenburg (Sweden).

\section{CHARACTERIZATIONS}

181 Measurement and characterization of IR thin film bandpass filters D. L. Stierwalt, Naval Ocean Systems Ctr.

$196 \mathrm{CO}_{2}$ jet spray cleaning of IR thin-film-coated optics R. C. Loveridge, Hughes Aircraft Co.

215 BTDF of $\mathrm{ZnSe}$ and BRDF of Ge with multilayer coatings at 3.39 microns

M. M. Yang, L. M. Scherr, K. Sorensen, GenCorp/Aerojet Electronic Systems.

231 Protective infrared transparent coatings

R. W. Tustison, Raytheon Co. 